\title{
Lipolytic Activity by Oral Pleuropneumonia-Like (Mycoplasma) Organisms
}

\author{
By B. C. COLE* AND PHYLLIS PEASE \\ Department of Virology and Bacteriology, University of Birmingham
}

(Accepted for publication 29 November 1966)

\begin{abstract}
SUMMARY
Ninety-five strains of Mycoplasma were isolated from human saliva; all were micro-aerophilic; 72 were actively lipolytic and 23 were non-lipolytic and were inhibited by Tweens. A type culture of human type 4 (Mycoplasma salivarum) was culturally identical with the lipolytic strains, and two type cultures of $M$. orale with the non-lipolytic strains. The strains serologically identifiable as $M$. orale were non-lipolytic, whereas those identifiable as $M$. salivarium were of both types. Comparison was also made with type strains from other sources. Those of human origin were non-lipolytic and those of saprophytic or animal origin were slightly lipolytic.
\end{abstract}

\section{INTRODUCTION}

Mycoplasma (PPLO) organisms were first isolated from the human mouth and pharynx by Smith \& Morton (1951) and by many workers since. Nicol \& Edward (1953) regarded them as distinct from human genital and veterinary strains, and Edward (1954) classified them on cultural grounds as human type 4, the genital strains being type 1. Huijsmans-Evers \& Ruys (1956) confirmed the distinction serologically, as also did Edward \& Freundt (1956) who named the oral strains Mycoplasma salivarium; Pease (1965) showed that, although the oral and genital strains were antigenically distinct, at least four antigens were common to both.

A second antigenic type of oral Mycoplasma was identified and given the name of Mycoplasma orale by Herderschee, Ruys \& van Rhijn (1963) and by Taylor-Robinson, Canchola, Fox \& Chanock (1964).

Lipid metabolism in Mycoplasma has attracted attention: Edward (1950) described the 'film and spots' reaction which he later (Edward, 1954) showed to be associated with lipid metabolism, and specifically to the clearing of egg yolk. Nicol \& Edward (1953) showed that some human type 4 strains produced this reaction, whereas others did not. The fatty-acid requirements of Mycoplasma strains were investigated by Razin \& Rottem (1963) and lipolytic activity recorded by Rottem \& Razin (1964). In the present paper, the lipolytic activity of some oral strains of Mycoplasma is described, and compared with that of named strains.

\section{METHODS}

Strains used. Ninety-five strains were isolated from human saliva in this laboratory; 5 strains of Mycoplasma hominis type 1, one each of $M$. salivarium (H 110 Edward), $M$. Mycoides (capri), M. gallinarum and $M$. laidlawii types A and B, all maintained as

\footnotetext{
* Present address, Department of Internal Medicine, University of Utah, U.S.A.
} 
type cultures in this laboratory; two strains of $M$. orale, Ella \& Hilverda, obtained from Dr A. C. Ruys. Generic and specific names are used for convenience without prejudice to the problem of their validity.

Media. The basal medium used consisted of $1 \%(\mathrm{w} / \mathrm{v})$ proteose peptone (Oxoid), $0.25 \%(w / v)$ yeast extract (Oxoid), $1 \%$ (w/v) Lab-Lemco (Oxoid beef extract) and $0.5 \%(\mathrm{w} / \mathrm{v})$ sodium chloride. The medium was adjusted to $\mathrm{pH} 7.8$ and sterilized by autoclaving at $120^{\circ}$ for $15 \mathrm{~min}$. Any precipitate which developed was removed by filtration, and the clear medium again autoclaved. When a solid medium was required, the broth was supplemented with $1 \cdot 2 \%(\mathrm{w} / \mathrm{v})$ New Zealand agar or $1 \%(\mathrm{w} / \mathrm{v})$ Ionagar no. 2 (Oxoid, L 12). Bovine serum, heated at $60^{\circ}$ for $30 \mathrm{~min}$. was added to a final concentration of $10 \%(\mathrm{w} / \mathrm{v})$. Horse serum was used only for the initial isolations because of the reproduction of the film-and-spots reaction by some mycoplasmas, which would interfere with the tests for lipolysis. The oral mycoplasma strains were normally incubated anaerobically, but aerobic growth was also examined. The remaining strains were grown aerobically. Tests were examined after 7 days of incubation.

Egg-yolk reaction. The basal medium agar was supplemented with $10 \%$ (w/v) egg yolk suspension (Oxoid, SR 47). Inoculated plates were examined up to 7 days for lipolysis indicated by the development of a film over the growth and precipitation in the agar, and for proteolysis indicated by a wide zone of clearing of the egg-yolk emulsion.

Lipolysis. Butter fat and castor oil were added to the solid medium in the form of $10 \%(\mathrm{v} / \mathrm{v})$ emulsions in distilled water, prepared by treatment with a Mullard ultrasonic drill, to give final concentrations of $0.5 \%(\mathrm{v} / \mathrm{v})$. The breakdown of tributyrin was tested on Oxoid tributyrin agar. Decomposition of butter fat and castor oil was indicated by a clearing of the emulsions and a film over the surface of the growth; the breakdown of tributyrin was indicated by a clearing of the emulsion. Breakdown of Tweens 20, 40, 60 and 80 was tested on base agar containing $2 \%(w / v)$ Tween and $0.01 \%(\mathrm{w} / \mathrm{v})$ calcium chloride. Decomposition was indicated by the production of a film over the growth and precipitation beneath the agar.

Serology. Gel-diffusion precipitin tests were made according to the technique of Pease \& Laughton (1965). Growth-inhibition tests (Edward \& Fitzgerald, 1954) were done on plates of basal medium agar with filter-paper discs soaked in undiluted rabbit antiserum. Fluorescent antigen antibody tests were observed by the use of fluorescein-linked fowl anti-rabbit serum on colony impression preparations (Chanock, Hayflick \& Barile, 1962). Antisera were prepared as described by Pease \& Laughton, (1965).

\section{RESULTS}

Of the 95 oral Mycoplasma strains isolated, 72 produced a strong reaction on eggyolk agar and showed lysis of tributyrin, butter fat, castor oil and Tweens 20, 40 and 60 , but not Tween 80 ; these strains grew rather poorly aerobically. The remaining 23 strains were non-lipolytic and were inhibited by Tweens; these strains grew very poorly indeed aerobically. Of the named strains, type 4 (Mycoplasma salivarium) was indistinguishable from the lipolytic group; $M$. gallinarum, $M$. mycoides (capri) and $M$. laidlawii (A and B) were slightly lipolytic; $M$. orale was non-lipolytic and closely resembled the non-lipolytic group (Table 1). 
Twenty strains were examined serologically by gel-diffusion precipitin reactions, growth inhibition and immunofluorescence, against type antisera for type 4 (Mycoplasma salivarium) and $M$. orale. Type strains of $M$. orale possessed one antigen (as observed by lines of precipitation) which was absent from type strain of type 4 . Five strains were serologically identifiable as $M$. orale, all were non-lipolytic; 15 were identifiable as type 4 , of which 12 were lipolytic and three non-lipolytic.

Table 1. Lipolysis by strains of Mycoplasma

\begin{tabular}{|c|c|c|c|c|c|c|c|c|}
\hline & $\begin{array}{l}\text { Egg-yolk } \\
\text { reaction }\end{array}$ & $\begin{array}{l}\text { Castor } \\
\text { oil }\end{array}$ & $\begin{array}{l}\text { Butter } \\
\text { fat }\end{array}$ & $\begin{array}{c}\text { Tribu- } \\
\text { tyrin }\end{array}$ & $\begin{array}{l}\text { Tween } \\
20\end{array}$ & $\begin{array}{c}\text { Tween } \\
40\end{array}$ & $\begin{array}{c}\text { Tween } \\
60\end{array}$ & $\begin{array}{c}\text { Tween } \\
80\end{array}$ \\
\hline $\begin{array}{l}\text { Oral strains (72) and } \\
M \text {. hominis, type } 4 \\
\text { Oral strains (23) and }\end{array}$ & + & $\mathbf{S}$ & + & $\mathbf{S}$ & + & + & + & - \\
\hline $\begin{array}{l}M \text {. orale } \\
\text {. }\end{array}$ & - & - & - & - & I & I & I & I \\
\hline M. hominis type 1 & - & - & - & - & I & I & I & I \\
\hline M. gallinarum & + & - & - & - & + & + & + & + \\
\hline M. mycoides (capri) & - & - & - & + & + & + & + & $\mathbf{s}$ \\
\hline M. laidlawii (A and $\mathrm{B})$ & - & - & - & $\mathbf{S}$ & I & + & + & $\overline{\mathbf{s}}$ \\
\hline
\end{tabular}
+ = positive reaction; - = negative; $S=$ weakly positive; $\mathrm{I}=$ growth inhibited.

These results show that two types of oral mycoplasmas are distinguishable by their lipolytic activity. Culturally, the lipolytic strains correspond to the type strains of Mycoplasma salivarium, and the non-lipolytic correspond both culturally and antigenically to the type strain of $M$. orale; both lipolytic and non-lipolytic strains, however, are found among those antigenically definable as $M$. salivarium. The saprophytic strains and those of animal origin examined are slightly lipolytic, and are not inhibited by the Tweens, whereas the human vaginal strains examined are nonlipolytic and, like $M$. orale strains, are inhibited by the Tweens.

This work was assisted by grants from the Arthritis and Rheumatism Council and the Medical Research Council.

\section{REFERENCES}

Chanock, R. M., Hayflick, L. \& Barile, M. F. (1962). Growth on artificial medium of an agent associated with a typical pneumonia and its identification as a PPLO. Proc.natn. Acad. Sci. (U.S.A.) 48, 41.

EDWARD, D. G. ff. (1950). An investigation of pleuropneumonia-like organisms isolated from the bovine genital tract. J. gen. Microbiol. 4, 4.

EDWARD, D. G. ff. (1954). The pleuropneumonia group of organisms: a review together with some new observations. J. gen. Microbiol. $10,27$.

EdWARD, D. G. ff. \& Fitzgerald, W. A. (1954). Inhibition of growth of pleuropneumonia-like organisms by antibody. J. Path. Bact. 68, 23.

EDWARD, D. G. ff. \& FreUndT, E. A. (1956). The classifications and nomenclature of organisms of the pleuropneumonia group. J. gen. Microbiol. 14, 197.

Herderschee, D., RuYs, A. C. \& VAN RhiJn, G. R. (1963). A new oral mycoplasma isolated from the tonsils of two patients suffering from scarlatina. Antonie van Leeuwenhoek 29, 368.

HuiJsman-Evers, A. C. M. \& RUYS, A. C. (1956). Micro-organisms of the pleuropneumonia group (family of Mycoplasmataceae) in man. II. Serological identification and discussion of pathogenicity. Antonie van Leeuwenhoeck 22, 377.

NiCOL, C. S. \& EDWARD, D. G. ff. (1953). Role of organisms of the pleuropneumonia-like group in human genital infections. Br. J. vener. Dis. 29, 141.

PEASE, P. E. (1965). Antigenic structure of PPLO (Mycoplasma hominis) and related bacteria. J. gen. Microbiol. 41, 299. 
Pease, P. E. \& Laughton, N. (1965). The antigenic structure of Haemophilus and Corynebacterium species from the human genital tract claimed to be associated with or derived from Mycoplasma hominis. J. gen. Microbiol. 41, 293.

RAZIN, S. \& RotTEM, S. (1963). Fatty acid requirements of Mycoplasma laidlawii. J. gen. Microbiol. $33,459$.

Rotrem, S. \& RAzIN, S. (1964). Lipase activity of mycoplasma J. gen. Microbiol. 37, 123.

SMITH, P. F. \& Morton, H. E. (1951). Isolation of pleuropneumonia-like organisms from the throats of humans, Science, N.Y. 113, 623.

Taylor-Robinson, D., Canchola, J., Fox, H. \& Chanock, R. M. (1964). A new identified oral mycoplasma (M. orale) and its relationship to other human mycoplasmas. Am. J. Hyg. 80, 135. 